\title{
Craniovertebral junction malformation in Northeastern Brazil: the myth of the Dutch colonization
}

\author{
Malformação da junção craniovertebral no Nordeste do Brasil: o mito da \\ colonização Holandesa \\ Claudio Henrique Fernandes Vidal ${ }^{1,2}$, Joacil Carlos da Silva², Cícero José Pacheco Lins ${ }^{3}$, Alessandra Mertens \\ Brainer-Lima4, Marcelo Moraes Valença,
}

\begin{abstract}
The high prevalence of craniovertebral junction malformation in Northeastern Brazil is historically associated with brachycephalic biotype (flat head), also common in this region. It has been postulated that this trait was introduced to this region by the Dutch during the colonial period in Brazil's history. Based on the confrontation of this paradigm against some historical facts, the authors concluded that the brachycephalic phenotype was inherited from prehistoric ancestors (Amerindians) who were already living in this region when white European men arrived.
\end{abstract}

Key words: platybasia, brachycephalic biotype, cranial junction malformation.

\section{RESUMO}

A alta prevalência de malformação da junção craniovertebral no Nordeste do Brasil é historicamente associada ao biótipo braquicefálico (cabeça chata), também comum nessa região. Postula-se que essa característica tenha sido introduzida na região pelos holandeses durante o período colonial da história do Brasil. Com base na confrontação desse paradigma com alguns fatos históricos, os autores concluem que o fenótipo braquicefálico foi herdado de ancestrais pré-históricos (ameríndios) que já habitavam a região no momento da chegada do homem branco europeu.

Palavras-Chave: platibasia, biótipo braquicefálico, malformação da junção craniovertebral.

The high prevalence of craniovertebral junction (CVJ) malformation among the population born in Northeastern Brazil has been described for a long time ${ }^{1,2}$. It is usually associated with brachycephalic biotype (flat head), that is common in this region.

Virchow's seminal works described higher levels of basilar invagination among inhabitants of the Islands of the North Sea, the Netherlands and the Territory of Bremen (apud Silva) ${ }^{1}$. $\mathrm{Silva}^{3}$ also described a doctoral thesis about this theme developed by Bogtstra in 1864 in the Netherlands. No other correlation was found between CVJ malformation and the Dutch.

Despite the lack of any specific publication about this issue, it is widely accepted that the high prevalent rates of CVJ malformation among individuals born in Northeastern Brazil came from miscegenation with the Dutch during the colonial period of Brazil's history ${ }^{2}$. The purpose of this article was to confront this paradigm against historical facts in order to verify the veracity of this assertion.

\section{DUTCH'S HABITS DURING THE COLONIAL PERIOD}

During their brief stay in Northeastern Brazil, the Dutch preserved the same habits of their homeland. In contrast to the Portuguese, which adapted very well to the local Amerindian culture, the Dutch that came here were people from the city

${ }_{1}^{1}$ Postgraduate Program on Neuropsychiatry and Behavioral Sciences, Health Sciences Center, Federal University of Pernambuco (UFPE), Recife PE, Brazil;

${ }^{2}$ Neurosurgeon, Health Sciences Center, UFPE, Recife PE, Brazil;

${ }^{3}$ Resident of Neurosurgery, Health Sciences Center, UFPE, Recife PE, Brazil;

${ }^{4}$ Radiologist, Health Sciences Center, UFPE, Recife PE, Brazil.

Correspondence: Claudio Henrique Fernandes Vidal; Rua Francisco da Cunha 206; 51020-041 Recife PE - Brasil; E-mail: vidal-claudio@ig.com.br

Conflict of interest: There is no conflict of interest to declare.

Received 13 October 2012; Received in final form 07 November 2012; Accepted 14 November 2012. 
and they imported from Europe all sorts of products, including basic subsistence items. Their diet was based on alcohol, conserves and salt. They ate just flour made from wheat because they didn't accept eating flour made from manioc ${ }^{4}$.

These formal habits and customs were also present in their interpersonal relationships. For sexual satisfaction, women were brought from the Dutch court. Silva ${ }^{4}$ described the Dutch as with little affection to "sexual exoticism". During this time, a large amount of the families from Pernambuco descended from a common Portuguese ancestor, Jerônimo de Albuquerque, also called "The Adam of Pernambuco" This fact illustrates the indulgence of the Portuguese in crossbred unions during this time.

These historical arguments allow the supposition that the contribution of the Dutch people to the ethnical constitution of Brazil's Northeastern population was not so significant. Another fact to confirm this hypothesis was the short time of their dominion in this region, of only 24 years. Another interesting observation is that the brachycephalic phenotype encompasses the whole territory of Northeastern Brazil, and this is far beyond the area of Dutch dominion during the colonial period of Brazil's history. During its peak, the Dutch's dominion in Brazil was in territories that ranged from Maranhão, in the north, to the São Francisco River, in the south, but this dominion was restricted to the coast line ${ }^{5}$. Instead, brachycephaly is more prevalent among people from the Northeastern hinterland (personal communication).

\section{THE BRACHYCEPHALIC PHENOTYPE HAS STILL BEEN PRESENT IN THE NORTHEASTH OF BRAZIL SINCE THE PREHISTORIC PERIOD}

In accordance with the more accepted theory, native inhabitants (before Columbus) of the Americas came from

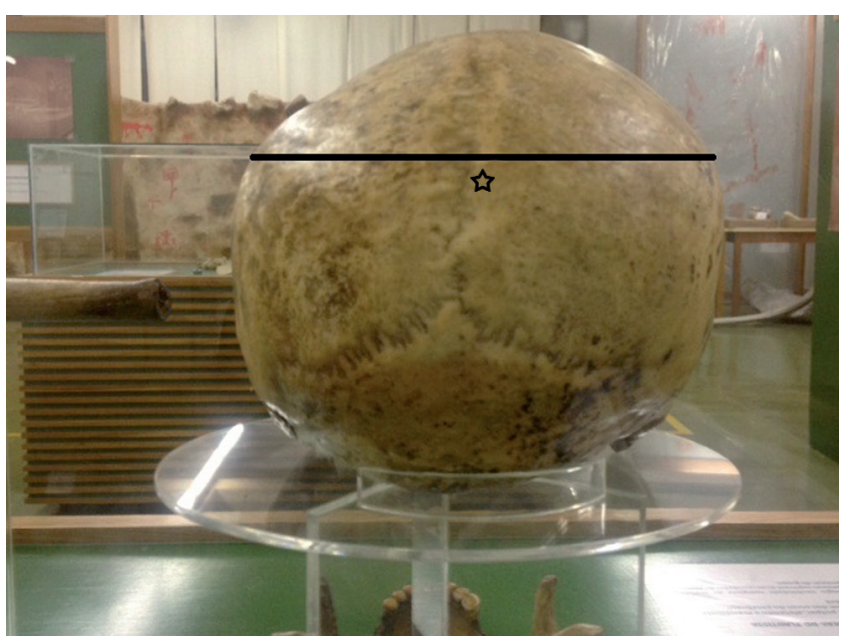

Fig 1. Cranium from the archaeological site of "Furna do Estrago" and in exposition at the Archaeological Department of Catholic University of Pernambuco. In a posterior to anterior view, a huge transversal dimension is observed (star). the Asiatic continent and settled through the Bering Strait, between 12,000 and 30,000 years ago ${ }^{6}$, corresponding to the last glacial era. Then, there occurred dispersion throughout the continent, from Siberia to the extreme tip of South America? Climate conditions during this time favored a high degree of population isolation and genetic drift $^{6}$.

In relation to cranial morphology, America's natives were split into two categories. The first one was characterized by long and narrow neurocraniums with low superior faces (nose and orbits). They lived during the Paleoindian period ( from 8,000 to 12,000 years ago). The second group was characterized by short and wide neurocraniums, with high faces (including nose and orbits). They lived during the Archaic period (less than 8,000 years ago $)^{7}$.

Two distinct scenarios have been raised to explain the morphological duality of the ancient cranium's form from South America. The first of them explains that these two different morphologies already arrived distinct in the New World, that is, two different populations from the Asiatic continent arrived in America between the final phase of the Pleistocene age and the beginning of the Holocene. The second sustains that Paleoamerican morphology (older) originated the Amerindian morphology (newer) by means of a local microevolutionary process, notably, genetic drift?

The excavation of the archaeological site of "Furna do Estrago" in "Brejo da Madre de Deus" city, Agreste of Pernambuco State, began in 1983. In an area of $125 \mathrm{~m}^{2}, 83$ human skeletons were discovered and dated from 2,000 years ago. There were also vestiges of older inhabitants, dated between 3,000 and 11,000 years ago, formed by prehistoric microfauna residues ${ }^{8}$.

Regardless if they had emigrated from Asia with these phenotypic features or if they had developed it locally by microevolutionary processes, studies of biologic anthropology disclosed that the rescued skeletons belonged to a population of brachycephalic individuals (Figs 1 and 2).

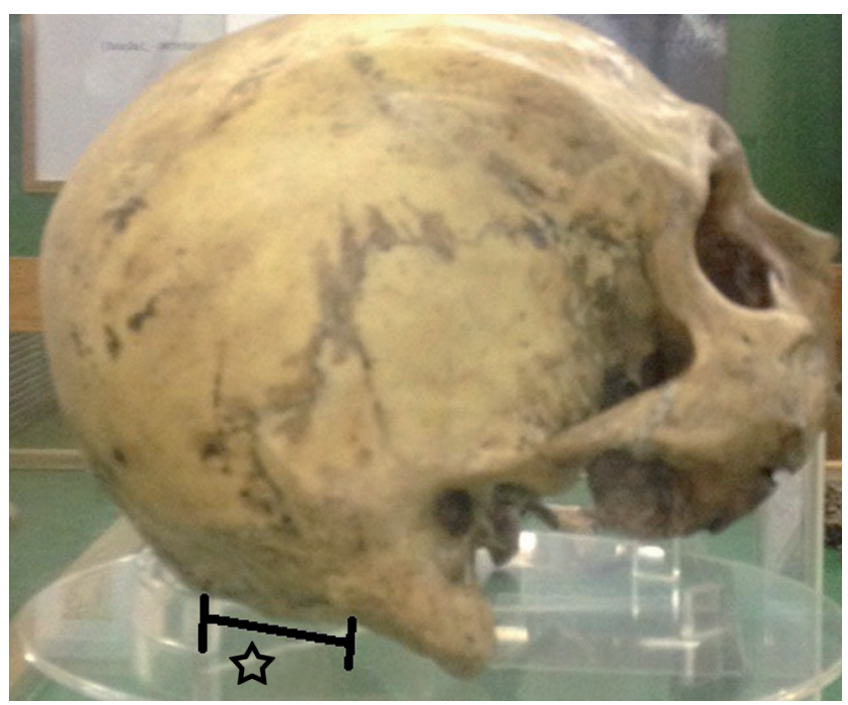

Fig 2. The same cranium in a lateral view. The occipital bone is horizontal and the posterior fossa is small (star). 
In this population, high frequencies of flaws of the closing of the neural arches (32.73\%) and extranumerary lumbar vertebra (36\%) were described. With lesser frequencies, flaws of the vertebral segmentation, structural defects of the ribs, dwarfism and abnormalities of the plates of the sternum were also described ${ }^{9}$. The high concentration of anomalies related with the development of the paraxial mesoderm may be linked to some genetic disorder 9 . The high index of consanguinity among this population, resulting from endogamous behavior, may explain the dissemination of some aberrant genetic conditions ${ }^{9}$. On the other hand, spinal dysrafisms are strongly related to environmental conditions, especially dietary habits ${ }^{10}$.
The limitation of nutrients in the region where the population lived could have unleashed the habitual intake of some teratogenic regional nutriment ${ }^{9}$.

In conclusion, based on historical facts discussed, it is licit to assume that the brachycephalic phenotype, so common among the people from Northeastern Brazil, was inherited from prehistoric ancestors (Amerindians) that had already lived in this region when white European men arrived. The short period of time of Dutch dominion in this region and their restrictive social habits curtailed the contribution of this ethnic group to the miscegenation process that culminated with the actual physical aspects typical of the people from Northeastern Brazil.

\section{References}

1. Silva JAG. Resultado do tratamento cirúrgico da impressão basilar e malformação de Arnold-Chiari: estudo de 72 casos [dissertation]. João Pessoa: Universidade Federal da Paraíba; 1977.

2. Barros MC, Farias W, Ataíde L, Lins S. Basilar impression and Arnold-Chiari malformation. J Neurol Neurosur Psychiatry 1968;31:596-605.

3. Silva JAG, Brito JCF. Histórico das malformações occipitocervicais. In: Silva JAG (ed). Malformações occipitocervicais. Recife: Editora Universitária/UFPE; 2003; p. 19-140.

4. Silva LD. Os holandeses e a vida social. In: Silva LD (ed). Holandeses em Pernambuco 1630-1654. 2a ed. Recife: Caleidoscópio;2011. p. 21-127.

5. Passetti G. A criação do mito do Brasil Holandês. Klepsidra: Revista virtual de História 2000;1 [cited 2012 March 16]. Available at: http://www.klepsidra.net/klepsidra3/holandeses.html
Santos FR, Pandya A, Tyler-Smith C, et al. The Central Siberian origin for Native American Y chromosomes. Am J Hum Genet 1999;64:619-628.

7. Neves WA, Bernardo DV, Okumura MMM. A origem do homem americano vista a partir da América do Sul: uma ou duas migrações? Rev Antropol 2007;50:9-44.

8. Lima J. Arqueologia da Furna do Estrago - Brejo da Madre de Deus/PE [dissertation]. Recife: Universidade Federal de Pernambuco (UFPE); 1986.

9. Carvalho OA. Análise das anormalidades de desenvolvimento na população pré-história do Sítio Furna do Estrago, Pernambuco [dissertation]. Rio de Janeiro: Escola Nacional de Saúde Pública; 1995.

10. Mitchell LE, Adzick NS, Mechionne J, Pasquariello PS, Sutton LN, Whitehead AS. Spina bifida. Lancet 2004;364:1885-1895. 